\title{
TACTILE LEARNING WITHIN THE EARLY PHASE OF EXPERIMENTAL AUTOIMMUNE ENCEPHALOMYELITIS IN MICE
}

\author{
Received December 28, 2012.
}

\begin{abstract}
The purpose of this study was to assess tactile learning in the early phase of experimental autoimmune encephalomyelitis (EAE), which was induced in C57BL/6 mice by subcutaneous injections on flank of myelin oligodendrocyte glycoprotein, MOG35-55 (250 $\mu \mathrm{g}$ per mouse). Tactile learning was assessed one week after EAE induction using the novel object recognition test (NORT) in a dark room. The procedure consisted of two phases. During the training phase (T1), the animals explored two similar objects; within the test phase (T2, occurring $4 \mathrm{~h}$ later) the mice explored one novel and one familiar object. On average, mice developed significant behavioral disabilities related to EAE $13.2 \pm 1.9$ days following immunization. In the EAE group, the locomotor activity level (assessed by measuring the distance travelled) in the T1 and T2 phases did not differ significantly, as compared to the related phases in the control group $(P>0.05)$. Within phase T1, no reliable differences were found for the frequency (number) of visits to the sample objects and for total exploration time between experimental groups. For phase T2, no difference was also found in the discrimination ratio when comparing the control group with the EAE group. Our study demonstrates that tactile learning in male mice may not be affected 7 days after immunization with MOG35-55 (i.e., within the early EAE phase).
\end{abstract}

Keywords: multiple sclerosis, experimental autoimmune encephalomyelitis, behavior, tactile learning.

\section{INTRODUCTION}

Multiple sclerosis (MS) is a progressive neurodegenerative disease of the CNS characterized by widespread lesions in the myelin sheaths of the fibers and damage to the gray matter [1]. There is a great diversity of motor, somatosensory, visual, coordination, and cognitive symptoms and signs in MS patients [2]. The attention of researches has only recently been focused on cognitive consequences in this disease. A loss of learning and memory abilities is the most common cognitive symptom evident in $40-65 \%$ of patients suffering from MS [3]. Certain types of memory are more intensely affected in this disease.

\footnotetext{
1 Physiology-Pharmacology Research Center, Rafsanjan University of Medical Sciences, Rafsanjan, Iran.

2 Department of pharmacology, School of medicine, Iran University of Medical Sciences, Tehran, Iran.

${ }^{3}$ Pharmacy Research Centre, School of Pharmacy, Mashhad University of Medical Sciences, Mashhad, Iran.

Correspondence should be addressed to A. Shamsizadeh

(e-mail: ashamsi@rums.ac.ir or alishamsy@gmail.com).
}

For example, it was reported that deficits in executive functions in MS patients occurs less frequently than memory or processing speed disabilities [4].

Experimental autoimmune encephalomyelitis (EAE) is one of the most used models for studying the etiopathogenesis of MS [5]. Despite being traditionally concentrated on motor dysfunction, some papers have recently reported that there are behavioral changes in EAE. According to Pollak et al. [6, 7], low social interaction and low sucrose consumption were induced in EAE mice when compared to the controls. On the other hand, there are reports demonstrating that spatial learning and recall (e.g., in the Morris water maze spatial memory test) were not impaired following induction of EAE in C57B1/6 mice [8].

In our study, we investigated tactile learning in a model of EAE induced in C57BL/6 mice.

\section{METHODS}

Animals. The animals were purchased from the Rafsanjan University of Medical Sciences. Mice were 
housed in groups (two to four per cage) and maintained at a $12 \mathrm{~h} \mathrm{light/dark} \mathrm{cycle} \mathrm{(lights} \mathrm{on} \mathrm{07:00} \mathrm{to} \mathrm{19:00)}$ with free access to food and water. The animal housing temperature was maintained at $23 \pm 2.0^{\circ} \mathrm{C}$. During the experiments, all animals were weighed every day.

Reagents. Myelin oligodendrocyte glycoprotein (MOG, Alexis Company, USA) along with complete Ferund's adjuvant (CFA), Cresyl Fast Blue, pertussis toxin, Luxol Fast Blue, and lithium carbonate (SigmaAldrich, USA) were used in our experiments.

Experimental Groups. Mice were randomly divided into three experimental groups with seven mice in each group as follows: (i) control, with no interventions, (ii) sham group, in which animals received CFA and pertussis toxin without MOG, and (iii) EAE group, where EAE was induced using MOG35-55, CFA, and pertussis toxin.

Induction of EAE in Mice. EAE was induced using a peptide, MOG35-55 (Alexis, USA), corresponding to the sequence of rodent MOG. Experimental mice received a subcutaneous injection on flank of $250 \mu \mathrm{g}$ MOG35-55 per mouse emulsified in CFA containing $0.4 \mathrm{mg}$ Mycobacterium tuberculosis. Animals also received pertussis toxin (500 ng per mouse) immediately after immunization and $48 \mathrm{~h}$ later [10]. In the sham-treated group, animals received CFA and pertussis toxin but did not receive MOG. Mice were monitored daily for weight loss and neurological signs of EAE. The severity of the disease among EAE mice was scored based on the method reported by Onuki et al. [9, 10]: grade 0 , no signs of disease; grade 1, partial loss of tail tonicity; grade 2 , loss of tail tonicity along with tail righting disabilities; grade 3, unsteady gait and mild paralysis of one hindlimb; grade 4, hindlimb paralysis and incontinence; grade 5, quadriplegia, and grade 6 , the animal was died.

Object Recognition Task. The object recognition task assesses recognition memory and is based on a natural tendency of animals to preferentially explore novel objects, as opposed to familiar objects [11]. The experimental apparatus was a Plexiglas box $(35 \times 35 \times 35 \mathrm{~cm})$ with a black plastic floor placed in a dimly illuminated room [12]. The objects to be discriminated were square and triangular iron blocks. The behavior of the mice was recorded by a camera positioned directly above the box and subsequently analyzed using Ethovison software (Noldus, Netherlands).

The object recognition task was done in three phases (habituation, training, and test phases) with a 24-h-long interval between the habituation and training phases and 4-h-long interval between the training and test phases. During the habituation phase, the mice were allowed to freely explore the box in the absence of objects for $30 \mathrm{~min}$. In the training phase (T1), each mouse was placed in the box with one object and was allowed to explore for $10 \mathrm{~min}$. To prevent side preference affecting the results, the position and shape of the object were changed after each animal was tested. All mice were placed in the box at the same point, and they were facing the same direction. Within the test phase (T2), each mouse was returned to the box where it was presented with a familiar object from the training trial (the position of this object was consistent between both training and test phases) and a novel object. Exploration time in phase T2 was 10 min (similar to that in T1). Care was taken to avoid olfactory stimuli by cleaning the box and objects with $70 \%$ ethanol between tests [13]. The time spent (sec) for exploring the objects was recorded. Exploration was defined as pointing the nose to the object at a distance $\leq 2 \mathrm{~cm}$. Climbing and/or sitting on an object were not considered as exploration. Within phase $\mathrm{T} 2$, the discrimination ratio was calculated as (total time spent in exploring both objects divided by the time spent exploring novel objects only) $100(\%)$. Mice showing a total exploration time $<10 \mathrm{sec}$ on either training or testing phases were excluded [13].

Statistical Analysis. Statistical analysis was performed using Excel and SPSS softwares. All data are expressed as means \pm s.e.m. Differences between the groups were determined using ANOVA followed by the Tukey post-hoc test. The paired $t$-test was also used to compare activity levels between the trial and test phases. For comparison of behavioral scores in the EAE group, we used repeated measurement ANOVA (RMA); $P$ values smaller than 0.05 were considered statistically significant.

\section{RESULTS}

Behavioral Scores. In the EAE group, the first statistically significant behavioral scores of EAE became apparent, on averaged, $13.2 \pm 1.9$ days after immunization. In this group, the behavioral scores increased to a peak level of $3.4 \pm 0.8$ (17 days following immunization; RMA, $P=0.049$ ). In the sham-treated group, we observed no behavioral scores of EAE throughout the period of study (Fig. 1).

Body mass changes. The mean body mass of mice in the EAE group on the 21 st day was significantly 


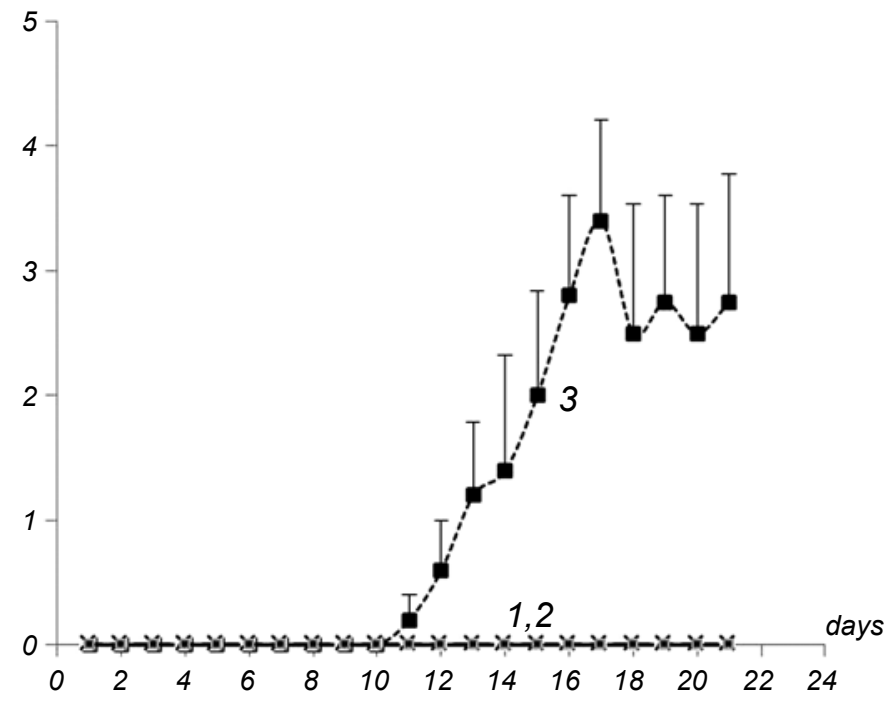

F i g. 1. Means of behavioral scores of mice in different groups. Abscissa) Days after immunization; ordinate) points. 1 and 2) Scores for the control and sham groups; 3 ) those for the EAE group.

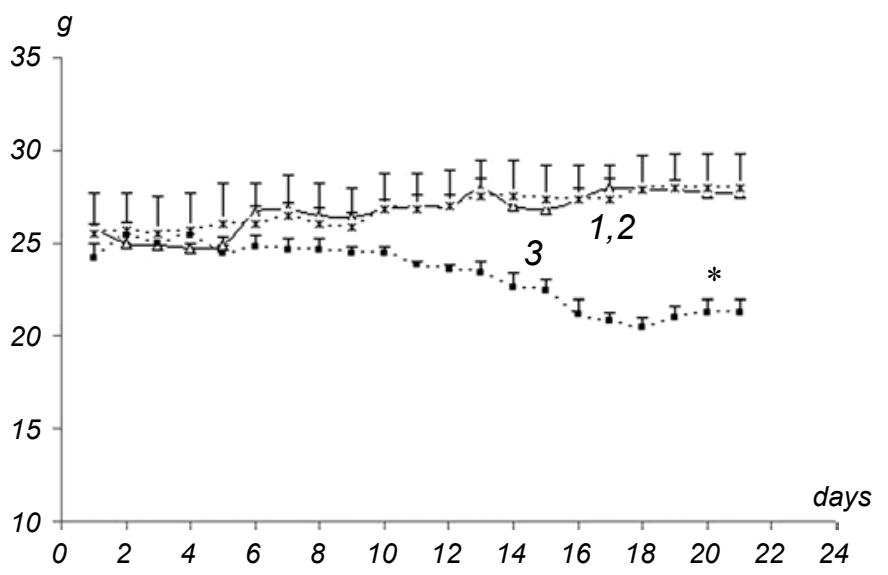

F i g. 2. Mean body mass ( $g$ ) of mice in different groups within the observation period. Designation of the groups is the same as in Fig. 1. Significant difference between day 1 and day 21 in the EAE group $(P=0.003)$ is shown by asterisk.

Р и с. 2. Середня маса тіла (г) мишей різних груп у межах спостережуваного періоду.

Р и с. 1. Середні величини поведінкових оцінок (бали) у мишей різних груп.

TABLE 1. Frequencies and Times of Visits with Respect to Novel or Familiar Objects within Phases T1 and T2 in Three Experimental Groups

Частота та тривалість обстеження нових та раніше досліджених об'сктів у межах фаз Т1 та Т2 у мишей трьох експериментальних груп

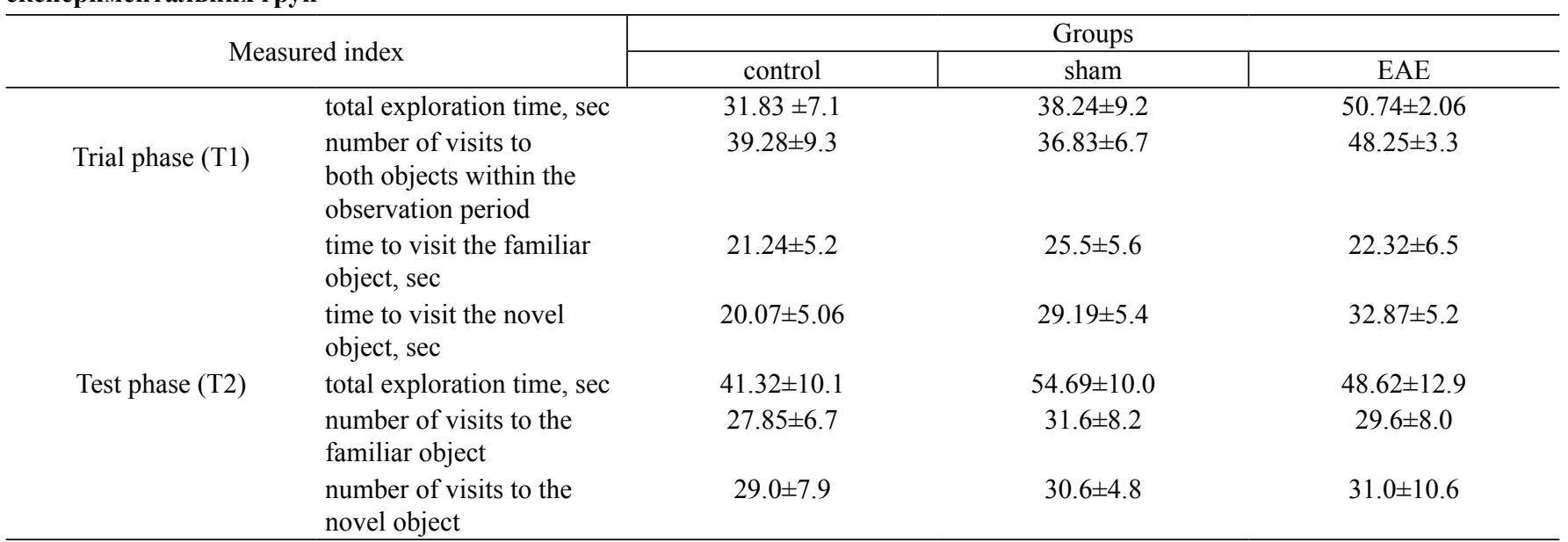

Footnotes. Data are expressed as means \pm s.e.m. The T2 phase was done $24 \mathrm{~h}$ after T1.

lower than their mean mass on the 1 st day $(P=0.003)$. For the sham and control groups, we did not observe any body mass loss throughout the study (Fig. 2).

Novel Object Recognition Test: Activity Level. The activity level was assessed by measuring the distance travelled during the trial (T1) and test
(T2) phases (Fig. 3). In the control group, the mean travelled distances in $\mathrm{T} 1$ and $\mathrm{T} 2$ did not differ significantly from each other $(P=0.6)$. In the sham group, the travelled distances in T1 and T2 were not significantly dissimilar $(P>0.05)$. In the EAE group, the travelled distances in $\mathrm{T} 1$ and $\mathrm{T} 2$ also did not differ 


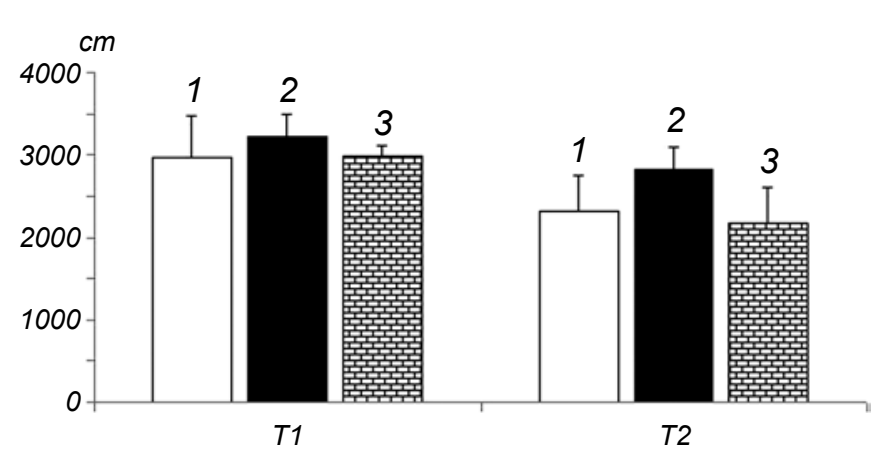

F i g. 3. Locomotor activity level in the control, sham-treated, and EAE (1-3, respectively) groups. The activity levels were measured according to the distance travelled within $10 \mathrm{~min}$ during both training and test phases (T1 and $\mathrm{T} 2$, respectively).

Р и с. 3. Рівень локомоторної активності мишей різних груп (контрольних, псевдоін'єкованих та 3 експериментальним аутоімунним енцефалітом, 1-3 відповідно).

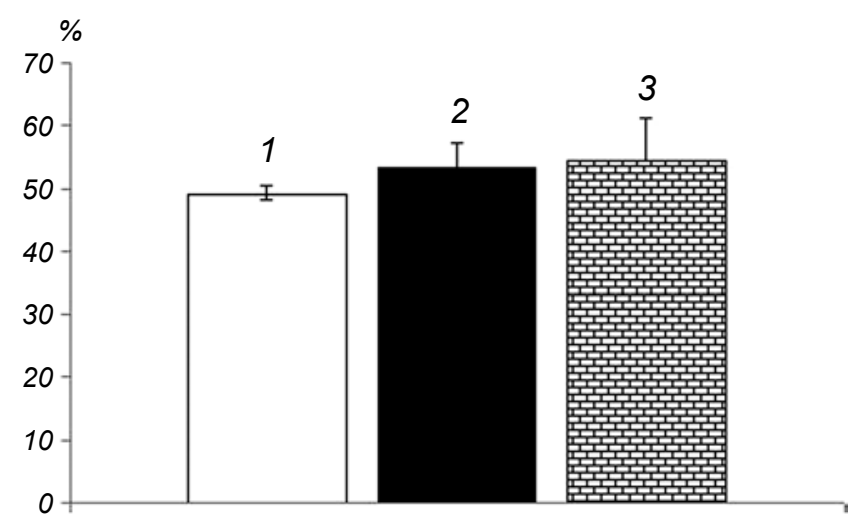

F i g. 4. Mean values of the discrimination ratio in different experimental groups. Designations are the same as in Fig. 3.

Р и с. 4. Середні величини коефіцієнта дискримінації у мишей різних експериментальних груп.

significantly from the respective values in the control group (all $P>0.05$ ). Thus, the levels of locomotor activity in all three groups demonstrated no significant differences despite the fact that some dissimilarities between the mean estimates were noticeable (Fig. 3).

Novel Object Recognition Test: Trial Phase (T1). The total time spent exploring one object in T1 (Table 1) was not statistically different in the control, sham, and EAE groups $(P>0.5)$. Similarly, no reliable differences were found between experimental groups for the frequency (number) of visits to sample objects $(P>0.09$; Table 1). Differences between the indices measured varied somewhat but demonstrated no systematic trends.
Novel Object Recognition Test: Test Phase (T2). Object exploration times during the test phase (T2) in experimental groups are shown in Table 1. No reliable differences were found for the time spent to explore novel and familiar objects between the experimental groups (all $P>0.05$ ). The mean of the total exploration time of both objects (familiar + novel) did not differ statistically from each other in the control and EAE groups $(P>0.05)$. Moreover, no reliable differences were found for the frequency of visits to the novel and familiar objects between experimental groups (all $P>0.05$; Table 1).

A comparison of the discrimination ratio (Fig. 4) between the experimental groups also revealed no difference $(P=0.3)$.

\section{DISCUSSION}

In our study, we were unable to find clear impairment of tactile learning (assessed by the novel object recognition test) in $\mathrm{C} 57 \mathrm{BL} / 6$ male mice within the acute phase of EAE.

Most neurodegenerative diseases, like Alzheimer's, Parkinson's, lateral sclerosis, and multiple sclerosis, exert deleterious effects on learning and memory, and these diseases mainly destroy integrative and cognitive abilities [14]. Experimental autoimmune encephalomyelitis (EAE) is the most frequently studied animal model used for elucidation of the underlying etiopathology of MS; this model has proved to be effective in the development of therapeutic strategy. EAE shares many clinical, histopathological, and immunological features of MS [15]. Nevertheless, there are some differences between EAE and MS. For example, in EAE, the CNS area primarily affected is the spinal cord. However, some recent studies have detected evidence of inflammation and neuronal changes in the brain of mice with EAE [16-19]. Because of brain dysfunction, behavioral disturbances in animals with EAE are to be expected. Thus, recent studies have been focused on cognitive deficits in EAE to find the possible mechanisms underlying cognitive defects.

Recently, Rodrigues et al. [20] checked the indices of memory and anxiety 9 and 60 days after induction of EAE with MOG35-55 in C57Bl/6 mice. They reported no differences in memory and anxiety when comparing controls and animals with induced EAE. In addition, $\mathrm{Tu}$ et al. [8], reported that spatial learning and recall (in the Morris water maze spatial memory 
test) were not affected following induction of EAE in $\mathrm{C} 57 \mathrm{Bl} / 6$ mice. Our results also demonstrated that tactile learning is not considerably impaired 7 days after induction of EAE in C57B1/6 mice. Based on these results, one may conclude that learning and memory is not affected within the early EAE phase. In EAE, it is well established that T-cell infiltration and inflammation are the main cause of CNS demyelinating lesions and neurodegeneration [16]. Therefore, it appears possible that brain inflammation should be associated with behavioral changes in EAE. There are reports demonstrating little sign of inflammation, T-cell infiltration, or neurodegeneration in the brain of EAE mice within the early period (7-10 days after immunization with MOG35-55) $[16,21]$. Conversely, there are some reports showing noticeable behavioral changes in EAE. Pollak et al. $[6,7]$ reported some behavioral sickness in the acute phase of EAE, including anorexia, decreased preference for sucrose solution, and reduced social exploration. It is worth mentioning that the cited authors used a dissimilar EAE model induced by a proteolipid protein in $\mathrm{SJL} / \mathrm{J}$ mice.

Although most studies on EAE reported that clinical signs of EAE would start 9-14 days post immunization [22], there are, however, some communications reporting that clinical signs of EAE start sooner than 7-14 days post immunization [23, 24]. Hence, we tested animals for tactile learning (by the novel object recognition test, NORT) before the appearance of EAE clinical signs (day 7 after immunization). As all behavioral tests depend on motor function, and as it seems that in EAE the behavioral changes coincide with the severe phase of the disease (within this phase, motor function is impaired), this imposes a limit for evaluating behavioral changes within the acute phase of EAE. For example, Jones et al. [21] reported that numbers of crossings in the open field test are dissimilar in EAE and control animals. However, it is not possible to conclude whether this outcome is a result of motor impairment or if it is a behavioral change. Some investigators used a mild model of EAE to solve this problem based on reduction of the amount of pertussis toxin [25]. While this seems a good strategy to decrease the motor impairment, the mechanisms that lead to the behavioral changes may be different.

Thus, the results of our study agree with observations reported in a few other studies and demonstrate little behavioral changes within the acute phase of EAE.
Procedures involving animals and their care were conducted in accordance with the Guide to the Care and Use of Experimental Animals (Olfert et al., Canada, 1993 [26]). Approval from the local Ethics Committee was also obtained.

The authors, F. Ayoobi, I. Fatemi, A. Roohbakhsh, and A. Shamsizadeh, have no conflict of interests.

The Physiology-Pharmacology Research Center and the Vice Chancellor of Research in the Rafsanjan University of Medical Sciences supported this study.

\section{Ф. Айюбі ${ }^{1}$, I. Фатемі ${ }^{1}$, А. Рухбахи ${ }^{1}$ А. Шамсизадех}

\section{ТАКТИЛЬНЕ НАВЧАННЯ В РАННІЙ ФАЗІ РОЗВИТКУ ЕКСПЕРИМЕНТАЛЬНОГО АУТОІМУННОГО ЕНЦЕФАЛОМІЄЛІТУ У МИШЕЙ}

${ }^{1}$ Дослідницький центр у галузі фізіології та фармакології Рафсанджанського медичного університету (Іран).

P е 3 ю м е

Розвиток експериментального аутоімунного енцефаломієліту (ЕАЕ) викликали у мишей за допомогою ін'єкцій мієлінового олігодендроцитарного глікопротеїну (MOG3555, 250 мкг на мишу). Здатність до тактильного навчання оцінювали через один тиждень після індукції ЕАЕ, використовуючи тест впізнавання нового об'єкта (NORT) у темному приміщенні. Процедура тестування складалася 3 двох фаз; протягом першої з них (Т1) тварини обстежували два однакових об'єкта, а в перебігу другої фази (Т2) миші обстежували один новий і один раніше обстежений об'єкти. Істотні поведінкові розлади, зумовлені ЕАЕ, розвивались у мишей в середньому через $13.2 \pm 1.9$ доби після імунізації. У групі ЕАЕ рівень локомоторної активності (оцінюваний за відстанню, котру тварини проходили в період обстеження) в межах фаз Т1 та Т2 не відрізнявся істотно від такого в контрольній групі $(P>0.05)$. У фазі Т1 не спостерігалося істотних міжгрупових різниць частоти (кількості) відвідань тест-об'єктів та загального часу, який було витрачено на ознайомлення з ними. У межах фази Т2 не виявлялося також достовірних різниць величин коефіцієнта дискримінації в контрольній та ЕАЕ-групах. Отже, наші тести показали, що, видимо, тактильне навчання мишей-самцівне піддається істотним змінам через сім діб після імунізації MOG35-55 (тобто в межах ранньої фази ЕАЕ).

\section{REFERENCES}

1. P. J. Jongen, A. T. Ter Horst, and A. M. Brands, "Cognitive impairment in multiple sclerosis," Minerva Med., 103, No. 2, 73-96 (2012).

2. M. L. B. Ferreira, "Cognitive deficits in multiple sclerosis: a systematic review," Arq. Neuropsiquiatr., 68, No. 4, 632-641 (2010).

3. R. H. Benedict and R. Zivadinov, "Predicting neuropsychological abnormalities in multiple sclerosis," 
J. Neurol. Sci., 245, Nos. 1/2, 67-72 (2006).

4. N. D. Chiaravalloti and J. DeLuca, "Cognitive impairment in multiple sclerosis," Lancet Neurol., 7, No. 12, 1139-1151 (2008).

5. L. Steinman and S. S. Zamvil, "How to successfully apply animal studies in experimental allergic encephalomyelitis to research on multiple sclerosis," Ann. Neurol., 60, No. 1, 12-21 (2006).

6. Y. Pollak, E. Orion, I. Goshen, et al., "Experimental autoimmune encephalomyelitis-associated behavioral syndrome as a model of depression due to multiple sclerosis," Brain, Behav., Immun., 16, No. 5, 533-543 (2002).

7. Y. Pollak, H. Ovadia, I. Goshen, et al., "Behavioral aspects of experimental autoimmune encephalomyelitis," J. Neuroimmunol., 104, No. 1, 31-36 (2000).

8. J. Tu, C. Zhao, T. Vollmer, et al., "APOE 4 polymorphism results in early cognitive deficits in an EAE model," Biochem. Biophys. Res. Commun., 384, No. 4, 466-470 (2009).

9. O. Costa, D. Divoux, A. Ischenko, et al., "Optimization of an animal model of experimental autoimmune encephalomyelitis achieved with a multiple MOG(35-55) peptide in C57BL6/J strain of mice," J. Autoimmun., 20, No. 1, 51-61 (2003).

10. M. Onuki, M. M. Ayers, C. C. Bernard, and J. M. Orian, "Axonal degeneration is an early pathological feature in autoimmune-mediated demyelination in mice," Microsc. Res. Tech., 52, No. 6, 731-739 (2001).

11. A. Ennaceur and J. Delacour, "A new one-trial test for neurobiological studies of memory in rats. 1: Behavioral data," Behav. Brain Res., 31, No. 1, 47-59 (1988).

12. B. Roozendaal, S. Okuda, E. A. Van der Zee, and J. L. McGaugh, "Glucocorticoid enhancement of memory requires arousal-induced noradrenergic activation in the basolateral amygdala," Proc. Natl. Acad. Sci. USA, 103, No. 17, 6741-6746 (2006).

13. B. Aisa, R. Tordera, B. Lasheras, et al., "Cognitive impairment associated to HPA axis hyperactivity after maternal separation in rats," Psychoneuroendocrinology, 32, No. 3, 256-266 (2007).

14. D. M. Arduino, A. R. Esteves, D. F. Silva, et al., "Therapeutic intervention at cellular quality control systems in Alzheimer's and Parkinson's diseases," Curr. Pharm. Des., 17, No. 31, 3446-3459 (2011).

15. A. Winkelmann, C. Engel, A. Apel, and U. K. Zettl, "Cognitive impairment in multiple sclerosis," J. Neurol., 254, Suppl. 2, 1135-1142 (2007).

16. D. A. Brown and P. E. Sawchenko, "Time course and distribution of inflammatory and neurodegenerative events suggest structural bases for the pathogenesis of experimental autoimmune encephalomyelitis," J. Comp. Neurol., 502, No. 2, 236-260 (2007).

17. D. H. Rodrigues, M. C. Vilela, L. S. Barcelos, et al., “Absence of PI3Кг leads to increased leukocyte apoptosis and diminished severity of experimental autoimmune encephalomyelitis," J. Neuroimmunol., 222, No. 1, 90-94 (2010).

18. D. H. Rodrigues, N. Lacerda-Queiroz, A. S. de Miranda, et al., "Absence of PAF receptor alters cellular infiltrate but not rolling and adhesion of leukocytes in experimental autoimmune encephalomyelitis," Brain Res., 1385, 298-306 (2011).

19. M. O. Ziehn, A. A. Avedisian, S. Tiwari-Woodruff, and R. R. Voskuhl, "Hippocampal CA1 atrophy and synaptic loss during experimental autoimmune encephalomyelitis, EAE," Lab. Invest., 90, No. 5, 774-786 (2010).

20. D. H. Rodrigues, M. C. Vilela, N. Lacerda-Queiroz, et al., "Behavioral investigation of mice with experimental autoimmune encephalomyelitis," Arq. Neuropsiquiat., 69, No. 6, 938-942 (2011).

21. M. Jones, T. Nguyen, C. Deboy, et al., "Behavioral and pathological outcomes in MOG 35-55 experimental autoimmune encephalomyelitis," J. Neuroimmunol., 199, No. 1, 83-93 (2008).

22. F. H. Peng, X. F. Zhong, X. Q. Hu, et al., "Effects of dendritic cell and subgroup changes on bone marrow transplantation treatment of multiple sclerosis," Neural Regener. Res., 4, No. 11, 874-878 (2009).

23. N. Popovic, A. Schubart, B. D. Goetz, et al., "Inhibition of autoimmune encephalomyelitis by a tetracycline," Ann. Neurol., 51, No. 2, 215-223 (2002).

24. E. Nizri, M. Irony-Tur-Sinai, N. Faranesh, et al., "Suppression of neuroinflammation and immunomodulation by the acetylcholinesterase inhibitor rivastigmine," J. Neuroimmunol., 203, No. 1, 12-22 (2008).

25. I. Peruga, S. Hartwig, J. Thöne, et al., "Inflammation modulates anxiety in an animal model of multiple sclerosis," Behav. Brain Res., 220, No. 1, 20-29 (2011).

26. E. D. Olfert, B. M. Cross, and A. A. McWilliam, Guide to the Care and Use of Experimental Animals, Canadian Council on Animal Care Ottawa, Ontario, Canada (1993). 